\title{
A RECUPERAÇÃO JUDICIAL À LUZ DO NOVO CÓDIGO DE PROCESSO CIVIL BRASILEIRO
}

\section{THE JUDICIAL REORGANIZATION UNDER THE APPROACH OF THE NEW BRAZILIAN CIVIL PROCEDURE CODE}

\author{
${ }^{1}$ Maria Cláudia Viana Hissa Dias do Vale \\ ${ }^{2}$ Natália Cristina Chaves
}

\section{RESUMO}

O objetivo deste artigo é demonstrar que a nova ordem processual civil brasileira permitiu uma leitura contemporânea dos processos de recuperação judicial, mediante a adoção de novos princípios e diretrizes aptos a proporcionar a justa distribuição dos ônus oriundos da superação da crise. Entre as inovações, há os meios alternativos de solução de conflitos, os quais são capazes de reduzir o acúmulo das demandas judiciais, substituindo-as por uma gestão mais democrática dos processos, que inclui todas as partes envolvidas. Conclui-se que, embora seja admissível a adoção de tais inovações no âmbito da Lei n. 11.101/2005, a sua escolha será casuística.

PALAVRAS-CHAVE: Recuperação Judicial; Código de Processo Civil; Empresário; Conflitos; Mediação

\begin{abstract}
This article aims to demonstrate that the new civil procedure order allowed for a contemporary analysis of judicial reorganization procedures, through the adoption of new guidelines that ensure the fair distribution of the burdens arising from the overcoming of the crisis. Among the innovations, there are the alternative methods of conflict resolution, which are capable of reducing the backlog of judicial demands, substituting them by a more democratic management of processes that includes all involved parties. It is concluded that, although the adoption of these innovations are allowed under the Law 11.101/2005, they will be chosen on a case-by-case basis.
\end{abstract}

KEYWORDS: Judicial Reorganization; Civil Procedure Code; Entrepreneur; Conflicts. Mediation

\footnotetext{
${ }^{1}$ Advogada. Especialista em Direito Civil pela Pontifícia Universidade Católica - PUC/Minas, Minas Gerais, MG, (Brasil). E-mail: m.claudia_viana@yahoo.com.br.

${ }^{2}$ Mestre e Doutora em Direito Empresarial pela Universidade Federal de Minas Gerais - UFMG, Minas Gerais, MG, (Brasil). Professora Adjunta do Departamento de Direito e Processo Civil e Comercial da Universidade Federal de Minas Gerais - UFMG, Minas Gerais, MG, (Brasil). E-mail: nataliacchaves@ uol.com.br.
} 


\section{INTRODUÇÃO}

Após inúmeras ondas reformatórias, o Código de Processo Civil de 1.973, aprovado durante a ditadura militar, cujas características revelavam o apego às formalidades e culminavam, por conseguinte, no afastamento das garantias constitucionais, revelou-se inapto aos modelos contemporâneos de processo.

Isso porque, como é sabido, o processo deve ser um instrumento de realização da ordem jurídica, mediante a entrega da efetiva prestação jurisdicional, em tempo razoável. Em linhas gerais, o processo somente atinge o seu fim com a obtenção do direito por seu detentor, após a consecução de procedimentos previamente estabelecidos, marcados pelos princípios do contraditório e da ampla defesa, sob o manto da celeridade.

Foi, então, em busca de um sistema de normas processuais condizentes com a sociedade atual, com fulcro na máxima de que o direito deve acompanhar a evolução social, que foi promulgada a Lei n. 13.105/2015 (o novo Código de Processo Civil - CPC), rompendo-se os paradigmas existentes e instituindo normas fundamentais de notório pano de fundo constitucional.

Diante do diálogo e das interações havidas entre o direito processual e o material, este último sofreu diretamente os impactos de modificações tão substanciosas. Com o direito concursal não foi diferente. A despeito da aplicação subsidiária do Código de Processo Civil à Lei n. 11.101/2005, haja vista o duplo caráter procedimental e material da aludida lei especial, não se pode olvidar os reflexos da nova ordem processual civil, imbuída do imperativo de um processo concursal célere, efetivo e democrático, preocupado com a distribuição equilibrada dos ônus entre as partes.

Sob essa nova perspectiva, é oportuno o exame do impacto da novel legislação processual civil no âmbito da recuperação judicial, especialmente quanto ao autorregramento do processo e os meios alternativos de solução de controvérsias.

O presente trabalho tem por objetivo captar a atenção do leitor para o tema, conectando duas áreas do direito que se complementam e instigando a experimentação de uma maior liberdade e cooperação das partes na condução da recuperação judicial, assegurando o cumprimento da finalidade do instituto, no sentido da preservação da empresa economicamente viável. Para tanto, foi feito um recorte, sendo que o impacto do novo CPC na Lei n. 11.101/2005 será analisado na esfera da recuperação judicial ordinária, não abrangendo a recuperação judicial especial facultada às microempresas e às empresas de 
pequeno porte, bem como a falência do devedor empresário.

\section{O ESTADO DEMOCRÁTICO DE DIREITO E O MODELO DE PROCESSO CONSTITUCIONAL À LUZ DO NOVO CÓDIGO DE PROCESSO CIVIL}

O Estado Democrático de Direito consubstancia-se a partir do ideal de salvaguarda dos direitos individuais, sociais e coletivos, bem como da preservação das garantias constitucionais. Sob essa perspectiva, a Constituição da República afigura-se como verdadeira limitadora da atuação estatal, que deve perquirir os direitos fundamentais consagrados, em observância às garantias constitucionais. ${ }^{3}$

A Constituição da República de 1.988, como não poderia deixar de ser, com o objetivo de evitar um governo autocrático, adotou o princípio da separação tripartite dos poderes, mantendo, no entanto, uma estrutura una e indivisível. ${ }^{4}$ Sobre a separação tripartite dos poderes, Alexandre de Moraes salienta a importância de "distinguir três funções estatais, quais sejam, legislação, administração e jurisdição, que devem ser atribuídas a três órgãos autônomos entre si, que as exercerão com exclusividade”. (MORAES, 2007, p. 385).

No que concerne ao Poder Judiciário, a Constituição da República de 1.988, enquanto norma programática, garantiu aos jurisdicionados o direito de acesso ao poder judiciário $^{5}$, o direito ao contraditório e à ampla defesa ${ }^{6}$, o direito à prestação jurisdicional célere $^{7}$ e, ainda, o direito à assistência judiciária gratuita aos hipossuficientes. ${ }^{8}$

\footnotetext{
${ }^{3}$ Conforme ensina Canotilho, "O Estado constitucional responde ainda a outras exigências não integralmente satisfeitas na concepção liberal-formal de Estado de direito. [...] Vale a pena reconstruir esta discussão. O Estado de direito cumpria e cumpre bem as exigências que o constitucionalismo salientou relativamente à limitação do poder político. O Estado constitucional é, assim, e em primeiro lugar, o Estado com uma constituição limitadora do poder através do império do direito". (CANOTILHO, 1999, p. 10).

${ }^{4}$ A esse respeito, cita-se o disposto no art. $2^{\circ}$ da Constituição da República de 1.988, segundo o qual: "São Poderes da União, independentes e harmônicos entre si, o Legislativo, o Executivo e o Judiciário".

${ }^{5}$ A Carta Magna, em seu art. $5^{\circ}$, inciso XXXV, previu o princípio da inafastabilidade da jurisdição, pelo qual toda e qualquer pessoa tem o direito de levar qualquer ameaça ou lesão à apreciação do Poder Judiciário.

${ }^{6} \mathrm{O}$ direito ao contraditório e à ampla defesa, consagrado no art. $5^{\circ}$, inciso LV, da Constituição da República de 1.988, não se limita aos processos judiciais, eis que a sua aplicação deve ser garantida, também, nos processos administrativos. Ademais, sob a ótica do novo CPC, o contraditório deve ser visto não mais como oportunidade concedida às partes de se manifestar no processo, mas como direito de influenciar e participar na construção do provimento jurisdicional. A ampla defesa, por sua vez, somente se caracteriza a partir da existência de defesa e de defesa técnica. Sobre o assunto, destaca-se o art. 10 do novo CPC, que assim preceitua: "O juiz não pode decidir, em grau algum de jurisdição, com base em fundamento a respeito do qual não se tenha dado às partes oportunidade de se manifestar, ainda que se trate de matéria sobre a qual deva decidir de ofício".

${ }^{7}$ A celeridade, já aclamada na Constituição da República de 1.988, em seu art. $5^{\circ}$, inciso LXXVIII, também foi reproduzida no novo CPC, especialmente em suas normas fundamentais. A esse respeito, destaca-se o art. $6^{\circ}$ do novo CPC: "Todos os sujeitos do processo devem cooperar entre si para que se obtenha, em tempo razoável, decisão de mérito justa e efetiva".
} 
Trata-se, a bem da verdade, dos desígnios do Estado brasileiro, os quais dependem de regulamentação legislativa para a sua execução e concretização, mas que não podem ser entendidos como meros protocolos de intenções. Diante de tal fim - materialização das normas e diretrizes constitucionais - o Código de Processo Civil revogado, excessivamente apegado à forma, não logrou êxito no cumprimento da função jurisdicional do Estado, no sentido da efetiva pacificação social, tornando-se moroso, burocrático, oneroso e, por conseguinte, ineficiente.

A simples leitura de trechos extraídos da Exposição de Motivos do Anteprojeto do novo Código de Processo Civil $^{9}$ é satisfatória para demonstrar a inaptidão do sistema anterior e a sua impotência em face das aspirações constitucionais.

Nesse contexto, sobreveio a Lei n. 13.105/2015, introduzindo, no ordenamento jurídico pátrio, um Código de Processo Civil reformador, que vestiu uma roupagem constitucional desde a sua elaboração, contando com a participação de diversos segmentos sociais (magistrados, advogados, membros do Ministério Público, procuradores, defensores públicos, professores, cartórios, entre outros) e a realização de várias audiências públicas, oportunizando o conhecimento e a interação popular. Nota-se, pois que um verdadeiro processo democrático foi instaurado.

Importantes mudanças foram trazidas, a começar pela preocupação em se apontar, já no primeiro capítulo do aludido Diploma, as normas fundamentais do processo civil, de cunho nitidamente constitucional e com inconteste matriz hermenêutica, obstando a interpretação isolada dos dispositivos legais. ${ }^{10}$

A instituição de normas fundamentais no bojo do Código de Processo Civil não objetivou, como bem asseveraram Dierle Nunes, Lenio Luiz Streck e Leonardo Carneiro da Cunha $^{11}$, apenas repetir o texto contido na Carta Magna de 1.988. Ao contrário, tais normas

\footnotetext{
${ }^{8}$ Acertadamente, a assistência judiciária devida aos hipossuficientes não se restringiu ao disposto no art. $5^{\circ}$, inciso LXXIV, da Constituição da República de 1.988. O novo CPC tratou da questão no seu art. 98 e seguintes, fazendo, inclusive, a distinção entre assistência judiciária gratuita e gratuidade da justiça.

${ }^{9} \mathrm{O}$ acesso ao Anteprojeto é livremente franqueado à população mediante acesso à página oficial do Senado Federal (www.senado.gov.br/senado/novocpc/pdf/Anteprojeto.pdf), a partir do qual é possível compreender com maior clareza o descompasso do Código revogado com a realidade atual.

${ }^{10}$ Humberto Theodoro Junior é enfático ao afirmar: "leituras isoladas de dispositivos e institutos, alheias às premissas fundamentais, tendem a ser equivocadas e a conduzir resultados práticos inaceitáveis". (THEODORO JUNIOR, 2015, p. 20).

${ }^{11}$ Reiteradamente, ditos autores salientaram a importância do texto constitucional, sem, contudo, desprestigiar o legislador que, por uma questão de técnica hermenêutica, optou por inserir, no novo CPC, tal matriz constitucional expressamente. A esse respeito, cita-se o seguinte trecho da obra dos autores: "É óbvio que boa parcela das normas fundamentais busca somente a expansividade do que está na Constituição e, caso fossem aplicadas com toda a sua força, tornariam desnecessário a repetição ou descrição de seu conteúdo pelo CPC2015”. (CUNHA; NUNES; STRECK, 2016, p. 234).
} 
fundamentais introduziram, efetivamente, um outro padrão de processo, pelo qual não se admite um protagonismo judicial, assegurando às partes o poder-direito de influenciarem na construção do provimento jurisdicional, alicerçadas em um contraditório substancial e em um arquétipo coparticipativo de processo. ${ }^{12}$

Constata-se, portanto, que a nova ordem processual civil, premida de uma visão constitucionalizada do processo, superou o padrão de julgamento fundamentado em uma verdade formal, com aparência de celeridade, que já não atendia aos seus fins.

Nesse contexto, ante um novo modelo de processo constitucionalizado, envolto em normas principiológicas, base interpretativa de todo o sistema, pode-se afirmar que o maior desafio dos operadores do direito será romper os paradigmas de um direito processual ultrapassado e arraigado à forma, seguindo as diretrizes traçadas pelas normas fundamentais insertas ao longo do novo Código de Processo Civil, em busca da concretização de um processo essencialmente democrático e apto à salvaguarda dos direitos e garantias constitucionais. É, pois, com esse olhar que a aplicação das normas de direito processual civil ao direito concursal deve ser examinada.

\subsection{PRINCÍPIOS DO DIPLOMA PROCESSUAL CIVIL INAUGURADO}

Como dito, o novo Código de Processo Civil revela um engajamento da norma na consecução das diretrizes delineadas constitucionalmente, a exemplo do art. $4^{\circ}$ do Diploma Processual Civil, o qual preceitua que "As partes têm o direito de obter em prazo razoável a solução integral do mérito, incluída a atividade satisfativa".

Trata-se de uma reformulação do já consagrado e citado princípio da duração razoável do processo, segundo o qual a efetiva prestação jurisdicional depende, necessariamente, da celeridade e da obtenção do direito reclamado por seu detentor.

O Código de Processo Civil, repita-se, impõe uma interpretação sistemática dos seus

\footnotetext{
12 A esse respeito, leciona Flávio Quinaud Pedron: "Sob as novas luzes, o processo, então, é espécie de procedimento, mas com um fator distintivo, a presença do contraditório (como direito das partes ao tratamento em simétrica paridade e a condição de coautores do provimento). Os vínculos de sujeição das partes perante o magistrado são substituídos por direitos de liberdade de participação (o que implica em contrapartida o dever de o magistrado respeitar tais direitos) demonstrando a todo o curso do processo, e principalmente, em sua decisão, que a mesma foi construída utilizando os argumentos trazidos pelas partes e acabando com o mito de que a decisão judicial é fruto de uma consciência discricionária exclusiva e subjetiva. Esse novo conceito de processo, presente finalmente no Código de Processo Civil de 2015 (CPC/2015) é a chave hermenêutica para qualquer início de leitura da nova legislação, bem como para a correta compreensão dos princípios constituidores da cláusula do Devido Processo (Constitucional)”. (PEDRON, 2015).
} 
dispositivos, valendo ressaltar que os seus arts. $6^{\circ}$ e 139 , inciso II reforçam a preocupação com a celeridade processual, imputando aos demais sujeitos do processo, incluindo-se as partes, juízes, advogados, representantes do Ministério Público e auxiliares, o dever de cooperação e de zelarem pela duração razoável do processo. ${ }^{13}$

Em atenção à aclamada celeridade processual, o novo Código de Processo Civil consagrou, nos parágrafos do art. $3^{\circ}$, o princípio da promoção, pelo Estado, dos meios alternativos de solução dos conflitos. ${ }^{14}$ Referida norma ganhou tal relevo que o processo de conhecimento passou a ter início com a realização de uma audiência de conciliação ou mediação, por um profissional apto e qualificado, com formação específica para a sua condução, salvo quando ambas as partes se manifestarem em sentido contrário.

Registra-se que essa norma já se encontrava presente na Lei n. 9.099/95, que dispõe sobre os Juizados Especiais Cíveis e Criminais e que, de igual modo, tem o termo inicial do processo marcado pela ocorrência da audiência de conciliação, em privilégio à autocomposição. A opção do legislador, no sentido de iniciar o processo a partir de um meio de solução alternativo do conflito, evidentemente, propicia atenuar a sobrecarga do Poder Judiciário. ${ }^{15}$ Ademais, em muitas situações de conflito, a melhor decisão é aquela criada pelas próprias partes, lastreada em seus interesses e experiências.

Outro princípio diretamente relacionado à celeridade processual é o princípio do respeito à ordem cronológica dos julgamentos, com exceções taxativas ${ }^{16}$, as quais não comprometem a finalidade da norma. ${ }^{17}$

\footnotetext{
${ }^{13} \mathrm{O}$ referido art. $6^{\circ}$ do novo CPC insere, no Diploma Processual, um conteúdo moral, pelo qual os sujeitos do processo têm o dever de manter uma postura colaborativa, em consonância com o princípio da boa-fé. Aliás, a inobservância a tal comportamento pode acarretar a aplicação de penalidades pelo juiz, a quem compete "velar pela duração razoável do processo", nos termos do citado art. 139.

${ }^{14} \mathrm{O}$ novo CPC deu especial atenção à mediação, à conciliação e à arbitragem. Tanto é assim que, posteriormente à aprovação do novo Código de Processo Civil, foi publicada a Lei da Mediação (Lei n. 13.140/15).

${ }^{15}$ Dados estatísticos do Conselho Nacional de Justiça (CNJ em números) revelam que a primeira instância do Poder Judiciário é a mais sobrecarregada em relação ao número de processos em tramitação. Os relatórios elaborados pelo CNJ revelam que, em 2015, havia 99,7 milhões de processos tramitando nacionalmente, sendo que $92 \%$ deles se encontravam nos fóruns brasileiros, com os juízes de primeiro grau.

${ }^{16}$ Sobre tais exceções, destaca-se o art. $12, \S 2^{\circ}$, do CPC, segundo o qual: "Os juízes e os tribunais atenderão, preferencialmente, à ordem cronológica de conclusão para proferir sentença ou acórdão. [...] §2 ${ }^{\circ}$ Estão excluídos da regra do caput: I - as sentenças proferidas em audiência, homologatórias de acordo ou de improcedência liminar do pedido; II - o julgamento de processos em bloco para aplicação de tese jurídica firmada em julgamento de casos repetitivos; III - o julgamento de recursos repetitivos ou de incidente de resolução de demandas repetitivas; IV - as decisões proferidas com base nos arts. 485 e 932; V - O julgamento de embargos de declaração; VI - o julgamento de agravo interno; VII - as preferências legais e as metas estabelecidas pelo Conselho Nacional de Justiça; VIII - os processos criminais, nos órgãos jurisdicionais que tenham competência penal; IX - a causa que exija urgência no julgamento, assim reconhecida por decisão fundamentada".

${ }^{17}$ Segundo Leonardo de Faria Beraldo, “[...] uma sentença proferida em desrespeito à ordem cronológica, sem a devida fundamentação do porquê disso, sugere que o magistrado esteja interessado no julgamento de causa em favor de qualquer das partes". (BERALDO, 2015, p. 9-10).
} 
A abrangência do princípio do contraditório, originariamente restrito à "paridade de armas", foi ampliada, ganhando "uma nova perspectiva, mais dinâmica, substancial e efetiva, onde as partes possuem mais influência no decidir do Magistrado. Assim, alcança-se a sua definição constitucional”. (DIDIER JR., 2015, p. 43).

E o legislador foi além. Como consequência lógica do princípio do contraditório aqui tratado como contraditório substancial, em que as partes têm o direito de participar e influenciar na construção da decisão jurisdicional - instituiu-se o princípio da vedação da decisão surpresa ${ }^{18}$, que garante às partes o direito de conhecerem e de se posicionarem sobre toda e qualquer matéria em discussão na lide, ainda que se admita o julgamento de ofício.

Exige-se, por conseguinte, um "dever de debate, consulta, de diálogo, de consideração" (WAMBIER, 2015, p. 445) entre os sujeitos do processo, o que não deixa dúvidas quanto ao conteúdo moral imputado à nova ordem processual civil. Tanto que o Superior Tribunal de Justiça, antes mesmo da vigência do novo Código de Processo Civil, já vinha se posicionando no sentido de que o princípio do contraditório, em seu aspecto substancial, está intimamente conexo com o princípio da boa-fé objetiva. ${ }^{19}$

Frisa-se que o princípio da boa-fé objetiva, já consolidado no direito material ${ }^{20}$, no novo Código de Processo Civil, restou expressamente previsto no seu art. $5^{\circ}$, segundo o qual "aquele que de qualquer forma participa do processo deve comportar-se de acordo com a boafé." Sobre a aplicação do princípio da boa-fé objetiva às relações processuais, Flávio Tartuce pondera que "a decisão judicial também passa a ser interpretada a partir da conjugação de

\footnotetext{
${ }^{18} \mathrm{O}$ princípio da vedação da decisão surpresa, nos termos do art. $9^{\circ}$ do novo $\mathrm{CPC}$, determina que: "Não se proferirá decisão contra uma das partes sem que ela seja previamente ouvida". Registra-se que a regra comporta exceções, as quais estão expressamente previstas nos incisos do parágrafo único do dispositivo legal aqui citado, quais sejam: a) tutela provisória de urgência; b) tutela de evidência fundada em prova documental; e c) liminar em ação monitória.

${ }^{19} \mathrm{O}$ Superior Tribunal de Justiça já se manifestou no sentido de que a boa-fé processual está intimamente relacionada ao princípio do contraditório, imputando tais deveres, inclusive ao Poder Judiciário. A esse respeito, confira: "[...] 8. É imperiosa a proteção da boa-fé objetiva das partes da relação jurídico-processual, em atenção aos princípios da segurança jurídica, do devido processo legal e seus corolários - princípios da confiança e da não surpresa - valores muito caros ao nosso ordenamento jurídico. 9. Ao homologar a convenção pela suspensão do processo, o Poder Judiciário criou nos jurisdicionados a legítima expectativa de que o processo só voltaria a tramitar após o termo final do prazo convencionado. Por óbvio, não se pode admitir que, logo em seguida, seja praticado ato processual de ofício - publicação de decisão - e, ademais, considerá-lo como termo inicial do prazo recursal. 10. Está caracterizada a prática de atos contraditórios justamente pelo sujeito da relação processual responsável por conduzir o procedimento com vistas à concretização do princípio do devido processo legal. Assim agindo, o Poder Judiciário feriu a máxima nemo potest venire contra factum proprium, reconhecidamente aplicável no âmbito processual". (REsp 1306463/RS, Relator Ministro Herman Benjamin, $2^{\mathrm{a}}$ Turma, julgado em 04/09/2012, DJe 11/09/2012).

${ }^{20}$ O Código Civil, fundamentado nas cláusulas gerais e nas diretrizes principiológicas, tratou, em seu art. 422, da aplicação do princípio da boa-fé objetiva aos contratos em geral. Tal princípio passou a ser considerado como
} 
todos os seus elementos e em conformidade com o princípio da boa-fé”. (TARTUCE, 2015, p. 36-37).

Destarte, com respaldo no princípio da boa-fé objetiva, que impregnou o novo Diploma Processual Civil, o processo abraçou o princípio do venire contra factum proprium. $^{21}$

Constata-se, portanto, que a boa-fé objetiva possui inegáveis funções interpretativa e de controle, norteando a conduta dos litigantes e viabilizando a punição daqueles que abusam do direito de acesso ao Poder Judiciário.

Nesse contexto, é inegável que o Código de Processo Civil, aproximando-se do direito material, inovou ao trazer em seu bojo princípios e cláusulas gerais que permitem a análise ampla da norma, casuisticamente, buscando a constitucionalização do processo.

\subsection{REGRAS INOVADORAS DA ORDEM PROCESSUAL CIVIL}

Traçados os princípios basilares do novo Código de Processo Civil, vale destacar algumas de suas regras que podem impactar no direito concursal.

Desde a postulação, os dispositivos legais do novo Código de Processo Civil foram significativamente modificados, com a drástica redução dos procedimentos disponíveis para a tramitação do feito. Nesse sentido, foram excluídos os procedimentos sumário e cautelar, de modo que o processo de conhecimento, ressalvadas as ações previstas em lei especial, passou a ser um só. As tutelas provisórias, antecipatórias ou incidentais, ganharam procedimentos próprios, admitindo-se, inclusive, a estabilização de decisões judiciais, proferidas em sede de urgência ou de evidência. Os pressupostos necessários ao deferimento das citadas tutelas provisórias também foram facilitados, assemelhando-se àqueles exigidos para as já conhecidas medidas cautelares atípicas. É oportuno registrar que as cautelares típicas não são mais reguladas, prevalecendo o poder geral de cautela.

O marco inicial do processo deixou de ser a citação para apresentação de resposta pelo réu, iniciando-se, agora, com a audiência de conciliação ou mediação, que somente não ocorrerá se ambas as partes se opuserem à sua realização.

Os prazos das partes passaram a ser contados em dias úteis, por força do art. 219 do

verdadeira fonte interpretativa das relações, norteando, também, a formalização dos negócios jurídicos (art. 113) e a teoria da responsabilidade civil (art. 187) no dito Codex.

${ }^{21} \mathrm{O}$ art. 187 do Código Civil preceitua que "Também comete ato ilícito o titular de um direito que, ao exercê-lo, excede manifestamente os limites impostos pelo seu fím econômico ou social, pela boa-fé ou pelos bons costumes". 
novo CPC.

Em sede recursal, o novo Código de Processo Civil criou um prazo único de 15 (quinze) dias úteis, exceto no tocante aos embargos de declaração, cujo prazo de 05 (cinco) dias foi mantido, agora computados em dias úteis. Houve uma delimitação das hipóteses de cabimento do agravo de instrumento no art. 1.015 do CPC. Por outro lado, concedeu-se maior flexibilidade na formação do instrumento. Os embargos infringentes foram excluídos do novo sistema recursal, substituídos por uma moderna técnica processual de julgamento. ${ }^{22}$

Paralelamente, passou-se a admitir um sistema de precedentes, que objetiva maior previsibilidade das decisões e, também, maior responsabilidade dos julgadores quanto ao dever de fundamentação. ${ }^{23}$

Outras alterações que podem ser citadas referem-se às regras relativas aos honorários advocatícios, que foram tratados com maior abrangência, incluindo-se a fixação dos honorários recursais. Os novos procedimentos para a desconsideração da personalidade jurídica da sociedade e para a criação de regras processuais próprias, estipuladas entre as partes, com a formulação de um calendário processual, também foram contempladas pelo novo sistema, em privilégio ao princípio do autorregramento da vontade no processo.

Com efeito, como se verá adiante, o novo Código de Processo Civil oportunizou às partes a possibilidade de criarem regras próprias para a tramitação do seu processo, privilegiando a autonomia da vontade. Também com fundamento na vontade das partes, o novo sistema incorporou a mediação e a conciliação como meios alternativos de resolução dos conflitos.

Ante tantas mudanças, verifica-se que foram postos à disposição das partes procedimentos mais céleres e eficazes, aptos à concretização de um processo democrático.

\section{A LEI 11.101/2005 E SUA BASE PRINCIPIOLÓGICA - APLICAÇÃO}

\footnotetext{
${ }^{22}$ Segundo o art. 942 do novo CPC: “Quando o resultado da apelação for não unânime, o julgamento terá prosseguimento em sessão a ser designada com a presença de outros julgadores, que serão convocados nos termos previamente definidos no regimento interno, em número suficiente para garantir a possibilidade de inversão do resultado inicial, assegurado às partes e a eventuais terceiros o direito de sustentar oralmente suas razões perante os novos julgadores".

${ }^{23}$ A partir da instauração de um sistema de precedentes, surgiram técnicas de julgamento. Nesse sentido: "O distinguishing expressa a distinção entre casos para o efeito de se subordinar, ou não, o caso sob julgamento a um precedente. A necessidade de distinguishing exige, como antecedente lógico, a identificação da ratio decidendi do precedente. Como a ratio espelha o precedente que deriva do caso, trata-se de opor o caso sob julgamento à ratio do precedente decorrente do primeiro caso. [...]. É possível que à substituição se dê eficácia $e x$ tunc (retrospective overruling), caso em que o precedente substituído não poderá ser invocado nem mesmo
} 


\section{SUBSIDIÁRIA DO CÓDIGO DE PROCESSO CIVIL}

A Lei n. 11.101/2005, que sucedeu o Decreto n. 7.661/45, regula a recuperação judicial, a extrajudicial e a falência dos devedores empresários. ${ }^{24}$ A partir da sua vigência, sobreveio uma substancial mudança no direito concursal, porquanto o seu enfoque se deslocou da relação entre o devedor empresário e os seus credores para o soerguimento econômico-financeiro da empresa, em prol dos interesses de toda a coletividade.

Em um primeiro momento, considerando o regime jurídico ao qual a empresa se submete, bem como as regras e princípios de direito empresarial, poder-se-ia pensar que a crise econômico-financeira enfrentada pelo devedor empresário não deveria ser objeto de intervenção do Estado. Todavia, a questão da dificuldade econômico-financeira do devedor empresário não fica adstrita ao particular, já que o exercício da atividade empresária afeta direitos e interesses de terceiros não conectados diretamente com o empresário. ${ }^{25}$

Tanto é assim que, ao tratar sobre a finalidade da recuperação judicial, a Lei n. 11.101/2005 apontou, expressamente, o objetivo de superação de tal crise, em seu art. 47:

Art. 47. A recuperação judicial tem por objetivo viabilizar a superação da situação de crise econômico-financeira do devedor, a fim de permitir a manutenção da fonte produtora, do emprego dos trabalhadores e dos interesses dos credores, promovendo, assim, a preservação da empresa, sua função social e o estímulo à atividade econômica.

O exame do mencionado dispositivo legal revela que a recuperação judicial é um procedimento que objetiva a preservação da empresa economicamente viável e a satisfação de sua função social, estimulando a atividade empresária. ${ }^{26}$

quanto a fatos anteriores à substituição, que ainda estejam pendentes de análise e julgamento pelos tribunais”. (MARINONI, 2013, p. 326).

${ }^{24}$ Para os fins do disposto neste trabalho, consideram-se devedores empresários os empresários individuais, as sociedades empresárias e as empresas individuais de responsabilidade limitada (EIRELI) que exerçam atividade empresária.

${ }^{25}$ No mesmo sentido: "Especificamente no campo do direito concursal, a relevância social e o reconhecimento do interesse público a ser por ele tutelado não são temas recentes, principalmente no que diz respeito às grandes empresas. [...] No âmbito do Direito nacional a valorização de novas perspectivas para lidar com a crise empresarial, tendo em vista interesses privados e públicos por ela abarcados, pode ser constatada tanto pelo fato de ter o legislador previsto institutos absolutamente novos voltados à preservação da empresa (recuperação judicial e extrajudicial) quanto pela profunda alteração de perspectiva com relação à falência, que passou a ser tratada como instrumento não apenas de liquidação, mas de preservação e otimização dos bens da empresa (art. 75)". (CEREZETTI, 2012, p. 231).

${ }^{26}$ Em privilégio ao princípio da preservação da empresa, o Superior Tribunal Federal já se manifestou no sentido de que "não se decreta a falência fundada em crédito inferior a 40 (quarenta) salários mínimos da data do pedido de falência, devendo o art. $1^{\circ}$ do Decreto-lei 7.661/45 ser interpretado à luz dos critérios que levaram à edição da Nova Lei de Falências". No mesmo sentido, a doutrina vem ensinando que: "O princípio da conservação da 
Aliás, o conceito de recuperação judicial, para a doutrina, busca "a manutenção da atividade empresarial, com o que também poderá manter o emprego dos trabalhadores". (GUIMARÃES, 2007, p. 126).

Como meio de viabilizar o reequilíbrio econômico-financeiro do devedor empresário, a Lei n. 11.101/2005 ampliou os meios de recuperação postos à disposição do devedor empresário, bem como o rol de credores sujeitos ao procedimento. ${ }^{27}$

Além disso, concedeu prazo de moratória para a exigibilidade de ações e execuções contra o devedor empresário, movidas por credores sujeitos ao procedimento recuperatório e obstou a retirada de bens essenciais à produção do seu estabelecimento, dentro de tal período. $^{28}$

No que se refere à legitimidade ativa do pedido de recuperação judicial, a questão é tratada no art. 48 da Lei n. 11.101/2005, o qual estabelece restrições ao devedor empresário para o pleito recuperacional, entre elas: a) não ser falido; b) não ter obtido há menos de 5 (cinco) anos a concessão de recuperação judicial; c) não ter sido condenado por crimes falimentares. Importante requisito a ser demonstrado pelo devedor empresário é a viabilidade econômica da atividade, que deverá ser detalhada no plano de recuperação judicial, apresentado nos moldes do art. 53 da Lei n. 11.101/2005, com a exposição dos meios pelos quais o devedor empresário buscará equacionar o seu endividamento, garantindo-se, por conseguinte, a manutenção de seus negócios sociais, criando caminhos alternativos à preservação da empresa.

Relevante inovação da Lei n. 11.101/2005 refere-se à ampliação do papel do administrador judicial, então chamado de comissário, na concordata e de síndico, na falência, de modo a fiscalizar, minuciosamente, a atividade do devedor empresário e o cumprimento do plano de recuperação judicial, requerendo a convocação de assembleia geral de credores não só nas hipóteses previstas em lei, mas também, quando entender necessária a oitiva de

empresa parte da constatação de que a empresa representa um valor objetivo de organização que deve ser preservado, pois toda a crise da empresa, causa um prejuízo à comunidade". (LOBO, 2011, p. 6).

${ }^{27}$ Nesse sentido, o art. $6^{\circ}, \S 4^{\circ}$, do novo CPC estabelece que: "A decretação da falência ou o deferimento do processamento da recuperação judicial suspende o curso da prescrição e de todas as ações e execuções em face do devedor, inclusive aquelas dos credores particulares do sócio solidário". Ao determinar a suspensão das ações e execuções ajuizadas contra o devedor empresário, pelo prazo máximo de 180 (cento e oitenta) dias, em decorrência do deferimento do procedimento recuperatório, a Lei n. 11.101/2005 objetivou propiciar a ele um ínterim de tranquilidade, durante o qual poderá se restabelecer e aprovar um plano de recuperação, "para que tenha o fôlego necessário para atingir o objetivo pretendido da reorganização da empresa, pois se as execuções continuassem, o devedor poderia ver frustrados os objetivos da recuperação judicial, em prejuízo, em última análise, da comunhão dos credores". (COELHO, 2005, p. 39). 
credores para a tomada de decisões.

A teor do art. 49 da Lei n. 11.101/2005, todos os créditos existentes à época do pedido de recuperação judicial sujeitam-se aos seus efeitos, excetuados aqueles previstos expressamente no dispositivo em comento.

Em relação aos credores, a Lei n. 11.101/2005, como regra, não admite a concessão de tratamento desigual entre os credores de uma mesma classe, sob pena de ofensa ao princípio da pars conditio creditorium. ${ }^{29} \mathrm{O}$ princípio a ser resguardado aqui não é o da isonomia meramente formal, mas, sim, material, que contempla a heterogeneidade dos credores, inclusive daqueles pertencentes a uma mesma classe. ${ }^{30}$

Outro princípio de destaque nos processos de recuperação judicial é o da distribuição equilibrada dos ônus, no sentido de que todos os envolvidos perdem um pouco em prol de um benefício maior que é a preservação da empresa. De acordo com tal princípio, busca-se "obter os benefícios sociais e econômicos que decorrem da recuperação da empresa". (COSTA, 2013).

No âmbito da recuperação judicial, o devedor empresário deve assumir os ônus oriundos de tal procedimento, atuando com transparência e em consonância com a boa-fé objetiva, buscando o reequilíbrio econômico-financeiro e, ainda, a manutenção da fonte produtora, dos postos de trabalho e da geração de riquezas. Sob essa ótica, a recuperação judicial não pode significar um meio de enriquecimento do empresário às custas do sacrifício de credores e de outras partes envolvidas.

Com a Lei n. 11.101/2005, pretendeu o legislador a superação do dualismo pendular presente na história evolutiva do direito concursal, ora a favor dos credores, ora a favor do devedor. $\mathrm{O}$ intuito foi o de distribuir, de forma equânime, os ônus oriundos do enfrentamento da crise, viabilizando a preservação da empresa e resguardando os direitos e interesses da

\footnotetext{
${ }^{28}$ Sobre a não retirada de bens do estabelecimento do devedor, o art. $49, \S 3^{\circ}$, da Lei n. 11.101/2005 dispõe que: "Estão sujeitos à recuperação judicial todos os créditos existentes na data do pedido, ainda que não vencidos".

${ }^{29}$ Sobre referido princípio, Raque Sztajn ensina que: "Tendo presente que o fim visado pela lei é a preservação da empresa, da atividade, evidente que se justifica inibir disputas entre credores de diferentes classes. Deixar de incluir obrigações vincendas, as derivadas de operações anteriores ao pedido, serviria para reduzir os prazos de pagamento. Se todos os contratos forem de execução instantânea, a instalação da crise poderá levar à imediata cessação das atividades, o que não interessa a ninguém. A prática demonstra que crédito é um dos componentes na circulação de bens em mercados. Daí a importância da norma ao buscar tornar eficiente o processo de análise da confiança que o credor deposita no seu devedor". (SZTAJN, 2005, p. 226-227).

${ }^{30}$ No tocante às classes de credores, cumpre esclarecer que: "[...] em cada recuperação judicial, os credores devem estar classificados segundo as peculiaridades das medidas necessárias ao saneamento e reorganização da empresa. Se, na falência, a própria lei classificou os credores para fins do pagamento, na recuperação judicial, cabe ao plano de recuperação judicial fazer essa classificação, tendo em vista as particularidades de cada caso. $\mathrm{O}$ princípio constitucional da igualdade e o princípio do tratamento paritário dos credores estão plenamente
} 
coletividade.

Observa-se, pois, que a Lei n. 11.101/2005 lastreia-se em consolidada base principiológica $^{31}$, sendo que a interpretação das normas atinentes ao direito concursal depende da aplicação dos seus respectivos princípios norteadores. ${ }^{32}$

A Lei n. 11.101/2005, além de traçar as normas aplicáveis ao instituto da recuperação judicial, cuidou de delimitar as especificidades do seu procedimento. Trata-se, portanto, de legislação de cunho material e instrumental, o que não afasta a aplicação do Código de Processo Civil, em caráter subsidiário. ${ }^{33}$

A propósito, ante a inexistência de incompatibilidade com a lei especial, as regras de contagem dos prazos processuais em dias úteis, bem como a adoção dos requisitos necessários à concessão das tutelas provisórias, de urgência ou de evidência, passam a ser aplicadas ao direito concursal.

Na mesma linha, o novo sistema recursal e seus prazos unificados também deverão ser aplicados à Lei n. 11.101/2005, quando esta for omissa. Quanto ao cabimento dos recursos, ainda está sujeito às hipóteses previstas na Lei n. 11.101/2005, sem o afastamento daquelas estabelecidas na norma processual civil. O sistema de precedentes, certamente, influenciará no julgamento dos recursos, tendo em vista os incidentes de assunção de competência ${ }^{34}$ e de resolução de demandas repetitivas. ${ }^{35}$ A propósito, quanto ao incidente de resolução de demandas repetitivas, a determinação legal de suspensão do processo principal pode gerar efeitos deletérios no curso da recuperação judicial, ante a pluralidade de interesses que abarca, razão pela qual a sua aplicação deve ser flexibilizada no processo recuperacional.

Ainda sobre a aplicação subsidiária da nova legislação processual civil ao direito

atendidos, no âmbito da recuperação judicial, quando libera tratamento igual aos credores iguais e desigual aos desiguais." (COELHO, 2012, p. 109-110).

${ }^{31}$ Miguel Reale afirma que "Os princípios são "verdades fundantes" de um sistema de conhecimento, como tais admitidas, por serem evidentes ou por terem sido comprovadas, mas também por motivos de ordem prática de caráter operacional, isto é, como pressupostos necessidades da pesquisa e da práxis". (REALE, 2003, p. 303).

${ }^{32}$ A aplicação dos princípios, no ordenamento jurídico brasileiro, está prevista na Lei de Introdução às Normas do Direito Brasileiro (Decreto-lei n. 4657/42), que detém a função de integrar o sistema normativo. Segundo o seu art. $4^{\circ}$, "Quando a lei for omissa, o juiz decidirá o caso de acordo com a analogia, os costumes e os princípios gerais de direito".

${ }^{3} 3$ O art. 189 da Lei n. 11.101/2005 prevê expressamente que: "Aplica-se a Lei no 5.869, de 11 de janeiro de 1973 - Código de Processo Civil, no que couber, aos procedimentos previstos nesta Lei”.

${ }^{34}$ Sobre a assunção de competência, destaca-se o disposto no art. 947 do novo CPC: "É admissível a assunção de competência quando o julgamento de recurso, de remessa necessária ou de processo de competência originária envolver relevante questão de direito, com grande repercussão social, sem repetição em múltiplos processos".

${ }^{35} \mathrm{O}$ incidente de resolução de demanda está previsto no art. 476 do novo CPC, que assim dispõe: "É cabível a instauração do incidente de resolução de demandas repetitivas quando houver, simultaneamente: I - efetiva repetição de processos que contenham controvérsia sobre a mesma questão unicamente de direito; II - risco de ofensa à isonomia e à segurança jurídica". 
concursal, chama-se a atenção para o procedimento a ser adotado nos pedidos de desconsideração da personalidade jurídica ${ }^{36}$, usuais na falência. Tais pedidos deverão se dar mediante a instauração de um incidente, sob o crivo do contraditório e da ampla defesa. ${ }^{37}$ Aqui também deve ser vista ressalva a previsão legal de suspensão do feito principal, o que poderá ser incompatível com o atendimento dos fins a que se destinam os institutos de direito concursal.

Outro ponto interessante na novel legislação processual civil é a regulação expressa da figura do amicus curiae, em seu art. 138, e que poderá intervir nos processos de recuperação judicial, a depender da "relevância da matéria, a especificidade do tema objeto da demanda ou a repercussão social da controvérsia", com poderes a serem definidos pelo julgador.

Sem prejuízo da especialidade da Lei n. 11.101/2005, não se pode olvidar que, em alguns momentos, a lei processual prevalecerá, em razão do seu viés constitucional, especialmente no tocante à aplicação das normas fundamentais.

Destarte, muitas novidades foram introduzidas pelo novo Código de Processo Civil no ordenamento jurídico pátrio, a fim de tornar os processos judiciais não somente mais célere, mas, em especial, mais democráticos e aptos à concretização dos direitos e garantias fundamentais.

\section{AUTORREGRAMENTO E MEIOS ALTERNATIVOS DE SOLUÇÃO DE CONFLITO - MEIOS DE EQUILIBRAR OS ÔNUS NA RECUPERAÇÃO JUDICIAL}

A despeito das especificidades de um processo de recuperação judicial, como já salientado, as normas fundamentais do novo Código de Processo Civil serão plenamente aplicáveis. ${ }^{38}$ Desse modo, no âmbito do direito concursal, impõem-se: a) a promoção dos métodos alternativos da solução dos conflitos; b) a celeridade processual como condição para

\footnotetext{
${ }^{36}$ Os procedimentos atinentes à desconsideração da personalidade jurídica estão previstos no art. 133 e seguintes do novo CPC.

${ }^{37}$ Conforme o art. 50 do Código Civil: "Em caso de abuso da personalidade jurídica, caracterizado pelo desvio de finalidade, ou pela confusão patrimonial, pode o juiz decidir, a requerimento da parte, ou do Ministério Público quando lhe couber intervir no processo, que os efeitos de certas e determinadas relações de obrigações sejam estendidos aos bens particulares dos administradores ou sócios da pessoa jurídica".

${ }^{38}$ A respeito da aplicação do novo CPC à Lei n. 11.101/2005, Flávio Luiz Yarshell ensina que: “[...]. Sem embargo da especialidade que marca o processo de recuperação, inspirado na preservação da empresa e calcado na vontade expressa pela maioria dos credores em assembleia, o fato é que ele é instrumento de exercício do poder estatal e, ao mesmo tempo, fator de legitimação das decisões ali tomadas. Portanto, isso quer dizer que, como em qualquer outro processo judicial - e aqui não importa a limitação trazida pelo art. 15 do novo diploma, aplicam-se o que o Código denominou de normas fundamentais”. (YARSHELL, 2015, p. 167).
} 
a efetiva prestação jurisdicional; c) o dever de boa-fé processual e de cooperação; d) o zelo pelo contraditório substancial e, por conseguinte, a vedação da decisão surpresa; e) o dever de fundamentação das decisões judiciais; f) o julgamento de acordo com a ordem cronológica de conclusão.

Em decorrência de tais normas, especialmente da imperiosidade da efetiva prestação jurisdicional que, como dito, abrange a celeridade processual e a integral solução do mérito, é admitido, nas ações de recuperação judicial, o autorregramento do processo.

O autorregramento dos processos, certamente, é uma das novidades mais ousadas no novo Código de Processo Civil, repousada no direito fundamental à liberdade. Fredie Didier Junior ensina que o autorregramento do processo pode ser verificado a partir de quatro aspectos, quais sejam: “a) liberdade de negociação; b) liberdade de criação; c) liberdade de estipulação; d) liberdade de vinculação". (DIDIER JR., 2016). Infere-se, pois que, a partir do autorregramento do processo, foi facultada às partes a possibilidade de escolherem quais são, no caso concreto, as melhores regras para a tramitação dos feitos, mediante a elaboração de um cronograma processual. ${ }^{39}$

Embora as ações de recuperação judicial não envolvam a configuração tradicional de autor e réu, nada obsta a adoção de um procedimento mais consentâneo com a realidade fática, inclusive para tratar dos prazos e sua contagem, dos deveres das partes, da escolha de peritos, entre outras questões processuais. Portanto, devedor e credores poderão alongar ou encurtar o prazo para a apresentação do plano de recuperação judicial, para apresentação de objeções, análise dos créditos, suspensão das ações e execuções em face do devedor empresário, entre outras determinações.

Contudo, ante a pluralidade de interesses envolvidos, tais assuntos deverão ser submetidos à aprovação em assembleia de credores, com a presença do devedor e seus credores, bem como do administrador judicial nomeado pelo juízo recuperacional. Além disso, tal aprovação dependerá do quórum ordinário previsto na lei especial. ${ }^{40}$

A esse respeito, são valiosas as lições de Flávio Luiz Yarshell:

\footnotetext{
${ }^{39}$ O novo CPC, em seu art. 191, prevê, expressamente, os negócios processuais, determinando que "De comum acordo, o juiz e as partes podem fixar calendário para a prática dos atos processuais, quando for o caso".

${ }^{40}$ A Lei n. 11.101/2005 estabelece quórum para as deliberações a serem realizadas em assembleias de credores, nos exatos termos do seu art. 42, segundo o qual "Considerar-se-á aprovada a proposta que obtiver votos favoráveis de credores que representem mais da metade do valor total dos créditos presentes à assembleia-geral, exceto nas deliberações sobre o plano de recuperação judicial nos termos da alínea a do inciso I do caput do art. 35 desta Lei, a composição do Comitê de Credores ou forma alternativa de realização do ativo nos termos do art. 145 desta Lei".
} 
[...] Trata-se de assunto que exige meditação. Contudo, na premissa de que os interesses envolvidos comportam autocomposição e de que vigora a plena capacidade dos interessados, não parece haver razão para se negar a vontade dos interessados; tanto mais em um modelo em que a vontade dos interessados tem tamanha relevância. Tal vontade, diante das peculiaridades da recuperação, poderia advir da vontade expressa pela maioria suficiente para deliberações em assembleia, e não necessariamente pela unanimidade dos credores. (YARSHELL, 2015, p. 169).

Registra-se, desde logo, que, na recuperação judicial, as deliberações ocorridas em sede de negócios processuais se limitarão às matérias que tratam sobre os seus ônus e deveres, mantendo-se resguardadas aquelas que são de competência do juízo da recuperação. ${ }^{41}$

Outro consectário da autonomia da vontade, no âmbito do processo civil, refere-se à adoção dos meios alternativos de solução amigável das controvérsias, inserta no $\$ 3^{\circ}$ do art. $3^{\circ}$ do novo Código de Processo Civil. ${ }^{42}$ A norma processual cita a conciliação e a mediação, sem prejuízo de outros métodos. A conciliação, já conhecida no âmbito dos Juizados Especiais, vem sendo tratada, também, como um procedimento preventivo, que visa impedir litígios. ${ }^{43} \mathrm{~A}$ conciliação pode, ainda, ocorrer incidentalmente ao processo judicial ${ }^{44}$, sendo que a transação acarretará a sua extinção, com resolução do mérito. ${ }^{45}$

Contudo, em alguns casos, a conciliação não se revela o meio alternativo mais adequado à pacificação, mormente quando há uma relação continuada entre as partes, como ocorre no direito concursal. Com efeito, a depender da questão em discussão, exige-se o conhecimento não só do problema aparente, mas, também, daqueles periféricos, para a efetiva e definitiva solução do conflito. A opção, então, passa a ser a mediação.

\footnotetext{
${ }^{41}$ Ao tratar a respeito dos negócios processuais, Humberto Theodoro Junior ensina que: "A possibilidade de as partes convencionarem sobre ônus, deveres e faculdades deve limitar-se aos seus poderes processuais, sobre os quais têm disponibilidade, jamais podendo atingir aqueles conferidos ao juiz. Assim, não é dado às partes, por exemplo, vetar a iniciativa de prova do juiz, ou o controle dos pressupostos processuais e das condições da ação, e nem qualquer outra atribuição que envolva matéria de ordem pública inerente à função judicante". (THEODORO JUNIOR, 2015, p. 470).

${ }^{42} \mathrm{O}$ art. $3^{\circ}$, caput, do novo CPC, ao tratar da inafastabilidade do Poder Judiciário prevê, também, em seu $\S 3^{\circ}$, o dever de promoção do Estado quanto aos meios alternativos de solução das controvérsias, assim dispondo: "Não se excluirá da apreciação jurisdicional ameaça ou lesão a direito. [...] $\S^{\circ}$ : A conciliação, a mediação e outros métodos de solução consensual de conflitos deverão ser estimulados por juízes, advogados, defensores públicos e membros do Ministério Público, inclusive no curso do processo judicial".

${ }^{43} \mathrm{O}$ CNJ já se posicionou no sentido de que a conciliação "constitui em um método de prevenção de litígios e funciona como opção alternativa ao ingresso na via judicial, objetivando evitar o alargamento do número de demandas nos foros e a abreviação de tempo na solução das pendências, sendo acessível a qualquer interessado em um sistema simples ao alcance de todos". (ALVES, 2008).

${ }^{44}$ O Manual do Conciliador, disponível no site do CNJ, vem se manifestando que "O acordo é uma melhor opção, não só porque resulta em uma solução mais rápida do problema, mas, principalmente, porque os senhores podem encontrar uma resposta que satisfaça a ambos, uma vez que conhecem melhor a questão do que qualquer outra pessoa possa vir a conhecer". (MANUAL DO CONCILIADOR, 2004, p. 20)

${ }^{45} \mathrm{O}$ art. 487 do novo CPC preceitua que "Haverá resolução de mérito quando o juiz: [...] III - homologar: [...] b) a transação; [...]".
} 
A Lei n. 13.140/2015 conceitua a mediação como sendo "a atividade técnica exercida por terceiro imparcial sem poder decisório, que, escolhido ou aceito pelas partes, as auxilia e estimula a identificar ou desenvolver soluções consensuais para a controvérsia". ${ }^{46} \mathrm{~A}$ doutrina, por sua vez, considera a mediação como "método alternativo ao judicial, especialmente apropriado à resolução de conflitos que envolvam pessoas com vínculo perene ou ao menos continuado no tempo, e seu foco é a busca de uma solução mutuamente satisfatória”. (BIANCHI; GARCEZ; MAIA, 2016, 50).

As características mais marcantes da mediação são: a) a voluntariedade; b) o sigilo; c) a autodeterminação; d) a cooperatividade; e e) a transdisciplinaridade. ${ }^{47}$ Pode-se afirmar, a partir da análise dos seus princípios, que o objetivo precípuo da mediação é o de "conhecer o conflito em sua complexidade, sem nenhuma opinião ou julgamento prévio". (MARTINS; ROSENBLAT, 2016, p. 145).

E tal procedimento vem se revelando extremamente eficaz na pacificação social, eis que diretamente relacionado à vontade e à liberdade das partes, garantindo segurança jurídica, porquanto a decisão construída pelos interessados gera a redução de descumprimento das obrigações e o afastamento de eventuais pedidos de revisão. Como se não bastasse, a mediação está em perfeita consonância com o imperativo de efetividade, pois evita os desgastes da morosidade e da onerosidade, ambas tão distantes dos anseios constitucionais. Em relação à mediação corporativa $^{48}$, desenvolvida como ferramenta de pacificação nas relações societárias, vem demonstrando um proeminente papel na retomada do diálogo no ambiente negocial, além de tratar de um meio de reduzir os impactos e custos financeiros para os empresários.

Partindo, então, da aplicação da mediação no âmbito corporativo é plenamente admissível a sua adoção no direito concursal, eis que, no aludido processo, são discutidos direitos disponíveis, para os quais é plenamente admitida a autocomposição. Com efeito, conjugando-se os princípios do autorregramento do processo e da soberania das decisões assembleares, pode-se definir as regras para a realização da mediação no âmbito das

\footnotetext{
${ }^{46} \mathrm{O}$ conceito de mediação foi extraído do art. $1^{\circ}$ da Lei n. 13.140/2015.

${ }^{47} \mathrm{O}$ art. $2^{\circ}$ da Lei n. 13.140/2015 dispõe acerca dos princípios da mediação. Confira: "Art. $2^{\circ}$ A mediação será orientada pelos seguintes princípios: I - imparcialidade do mediador; II - isonomia entre as partes; III - oralidade; IV - informalidade; V - autonomia da vontade das partes; VI - busca do consenso; VII - confidencialidade; VIII boa-fé".

${ }^{48}$ Em relação à mediação corporativa, a doutrina tem ressaltado o papel dos advogados na sua realização, de modo que "continua sendo papel do advogado o de defender os interesses do seu cliente; mas, um bom conhecimento do processo de mediação, que permite que ele aproveite tudo o que esse processo pode oferecer ao seu cliente". (BURBRIDGE; MANFREDI, 2015, p. 357).
} 
recuperações judiciais.

A priori, frisa-se, não se vislumbra qualquer incompatibilidade de diálogo entre as leis especiais - Lei $11.101 / 2015$ e a Lei n. 13.140/2015 - as quais, aplicadas em conjunto, podem alcançar o mandamento constitucional de celeridade e efetividade, ainda mais se considerada a suspensão dos processos no curso da mediação, a qual não impede a análise dos pedidos formulados em caráter de urgência. ${ }^{49}$

A fim de se alcançar uma maior efetividade, entende-se que o momento mais adequado à mediação é quando se inicia o processo de recuperação judicial, podendo ser impulsionada pelo devedor empresário, em sua petição inicial, pelos credores, administrador judicial e o próprio julgador.

No âmbito da recuperação judicial, o administrador judicial é a pessoa mais adequada para atuar como mediador. Durante a mediação, ao lado dos deveres impostos pela Lei n. 13.140/2015, o administrador judicial preservaria a função que lhe foi atribuída pela Lei n. $11.101 / 2005^{50}$, zelando pelo cumprimento das obrigações assumidas e fiscalizando a atuação do devedor empresário e de seus credores, de conformidade com o princípio da boa-fé processual e com o dever de cooperação.

Registra-se que, no curso da mediação, devedor e credores devem agir com lealdade e transparência, afastando-se a animosidade comum do processo judicial, para viabilizar a composição. Ao longo da mediação, as partes podem debater, amplamente, o plano de recuperação judicial e ainda que não cheguem a um acordo, podem identificar pontos de convergência, minimizando o embate no curso do processo. Portanto, o devedor empresário já apresentaria um plano contemplando os pontos de consenso debatidos na mediação. Por outro lado, havendo um acordo, algumas etapas do processo de recuperação judicial seriam eliminadas, passando-se, diretamente, ao controle de legalidade do plano acordado na mediação, pelo Poder Judiciário. ${ }^{51}$

\footnotetext{
${ }^{49}$ Nesse sentido, o art. 16 da Lei n. 13.140/2015 determina que: "Ainda que haja processo arbitral ou judicial em curso, as partes poderão submeter-se à mediação, hipótese em que requererão ao juiz ou árbitro a suspensão do processo por prazo suficiente para a solução consensual do litígio. [...] § $2^{\circ}$ A suspensão do processo não obsta a concessão de medidas de urgência pelo juiz ou pelo árbitro".

${ }^{50}$ Os deveres do administrador judicial estão previstos na Lei n. 11.101/2005, especialmente em seu art. 22 e incisos. Em síntese, o administrador tem o dever de fiscalização, de convocação de assembleias quando entender necessário, de representação ativa e passiva do devedor empresário.

${ }^{51} \mathrm{Na}$ mediação, assim como no procedimento ordinário de recuperação judicial, o juízo não exercerá um papel protagonista, eis que a sua função e restringirá à concessão da recuperação, após a formalização de um acordo e, por conseguinte, a aprovação do plano de recuperação. No mesmo sentido, cita-se o disposto no art. 58 da Lei n. 11.101/2005: "Cumpridas as exigências desta Lei, o juiz concederá a recuperação judicial do devedor cujo plano não tenha sofrido objeção de credor nos termos do art. 55 desta Lei ou tenha sido aprovado pela assembleia-geral de credores na forma do art. 45 desta Lei".
} 
Um dos óbices à adoção da mediação na recuperação judicial é o fato de não envolver duas partes contrapostas (autor-réu), como em um processo judicial tradicional. Por abarcar credores com características heterogêneas e que, mesmo pertencentes a uma mesma classe, podem estar em dissintonia, dificulta-se o consenso e até mesmo a adoção de uma solução que contemple, de forma satisfatória, todos os interesses envolvidos. De todo modo, ainda assim, a mediação é um instrumento útil a reduzir os conflitos e a possibilitar um maior diálogo entre todos os envolvidos, viabilizando a adoção de um plano que distribua, de modo mais equitativo, os ônus da recuperação judicial.

Partindo-se do autorregramento do processo e, por conseguinte, da adoção dos meios alternativos de solução das controvérsias, é possível afirmar que o novo Código de Processo Civil colocou, à disposição das partes envolvidas na recuperação judicial, procedimentos aptos à salvaguarda da preservação da empresa e da sua função social. Isso porque, a partir de tais institutos, é possível amenizar o desequilíbrio existentes entre os ônus suportados pelo devedor empresário e os seus credores, alcançando-se uma solução mais satisfatória a todos, na medida em que eles próprios constroem o provimento final.

Trata-se, a bem da verdade, de um sistema multiportas, que cria caminhos opcionais a uma gestão democrática do processo, que divide os deveres de lealdade e cooperação entre credor e devedores, "fundamental em qualquer tipo de processo, mas crucial no caso das recuperações judiciais, de modo que o tempo do processo não esteja dissociado do tempo da realidade ou da economia". (COSTA, 2013).

Nesse contexto, alicerçada nas normas fundamentais do novo Código de Processo Civil, que privilegiaram a autonomia da vontade, a recuperação judicial pode se tornar mais democrática, possibilitando o efetivo cumprimento da sua finalidade.

\section{CONCLUSÃO}

A Constituição brasileira de 1.988 traçou as diretrizes necessárias à salvaguarda dos direitos e garantias constitucionais. Com o mesmo intuito, o novo Código de Processo Civil, respaldado em suas normas fundamentais, inaugurou um novo caminho para os processos judiciais, privilegiando a liberdade dos jurisdicionados.

A autonomia da vontade, refletida no autorregramento do processo e na adoção voluntária dos métodos alternativos de solução dos conflitos, viabiliza o diálogo das leis especiais, de modo a tornar os processos concursais mais efetivos e menos desequilibrados. 
O presente trabalho objetivou contribuir, ainda que de maneira singela, para o pensamento de um novo modelo de recuperação judicial, com uma gestão mais democrática, sem, contudo, se afastar da sua finalidade, no sentido do efetivo soerguimento do devedor empresário.

As normas são recentes e o caminho promissor, cabendo às partes a escolha de como trilhá-lo.

\section{REFERÊNCIAS}

ALVES, Rafael Oliveira Carvalho. Conciliação e acesso à justiça. Webartigos, 20 nov. 2008. Disponível em http://www.webartigos.com/articles/11585/1/Conciliacao-e-Acesso-aJustiça/pagina1.html. Acesso em: 22 set. 2016.

BERALDO, Leonardo de Faria. Comentários às inovações do Código de Processo Civil. Belo Horizonte: Del Rey, 2015.

BIANCHI, Angela Andrade; GARCEZ, José Maria Rossani; MAIA, Andrea. Origens e norteadores da mediação de conflitos. In: ALMEIDA, Tania; PELAJO, Samantha; JONATHAN, Eva (Coord.). Mediação de conflitos para iniciantes, praticantes e docentes. Salvador: JusPodivm, 2016, p.49-51.

BRASIL. Conselho Nacional de Justiça. [S.I.]. Disponível em: http:// cnj.jus.br/programase-acoes/politica-nacional-de-priorizacao-do-1-grau-de-jurisdicao/dados-

estatisticospriorizacao. Acesso em: 22 set. 2016.

BRASIL. Exposição de motivos do anteprojeto da Lei n. 13.105, de 08 de junho de 2010. Disponível em: https://www.senado.gov.br/senado/novocpc/pdf/Anteprojeto.pdf. Acesso em 22 set. 2016.

CANOTILHO, J. J. Gomes. Estado de direito. Lisboa: Gradiva, 1999.

CEREZETTI, Sheila Christina Neder. A recuperação judicial de sociedade por ações: o princípio da preservação da empresa na Lei de Recuperação e Falência. São Paulo: Malheiros, 2012.

COELHO, Fábio Ulhôa. Curso de direito comercial. v. 1. 11ª ed. São Paulo: Saraiva, 2005.

COELHO, Fábio Ulhôa. O credor colaborativo na recuperação judicial. In: SATIRO, Francisco; TOLEDO, Paulo Fernando Campos Salles de (Coord.). São Paulo: Quartier Latin, 2012. p. 101-118.

COSTA, Daniel Carnio. Teoria da distribuição equilibrada dos ônus na recuperação judicial da empresa. 04 de novembro de 2013. Disponível em http:// http://www.cartaforense.com.br/conteudo/artigos/teoria-da-distribuicao-equilibrada-dos-onusna-recuperacao-judicial-da-empresa/12371. Acesso em: 23 set. 2016. 
CUNHA, Leonardo Carneiro da; NUNES, Dierle; STRECK, Lenio Luiz. Comentários ao Código de Processo Civil. $1^{\text {a }}$ ed. São Paulo: Saraiva, 2016.

DIDIER JR., Fredie. Curso de direito processual civil: teoria da prova, direito probatório, ações probatórias, decisão, precedente, coisa julgada e antecipação dos efeitos da tutela. v. 2. 10 a ed. Salvador: Jus Podivim, 2015.

DIDIER JR., Fredie. Princípio do respeito ao autorregramento da vontade no processo civil. Revista Páginas de Direito, Porto Alegre, ano 15, $\mathrm{n}^{\circ} 1250,01$ de junho de 2015. Disponível em: http://www.tex.pro.br/index.php/artigos/306-artigos-jun-2015/7187-principiodo-respeito-ao-autorregramento-da-vontade-no-processo-civil. Acesso em: 23 set. 2016.

GUIMARÃES, Maria Celeste Morais. Recuperação judicial de empresas e falência. $2^{\mathrm{a}}$ ed. Belo Horizonte: Del Rey, 2007.

LOBO, Jorge. Comentários à Lei de Recuperação de Empresas e Falência. São Paulo: Saraiva, 2011.

MANUAL DO CONCILIADOR. [S.I.], 8 jan. 2008. Disponível em: http://jrlfernandes.blog.uol.com.br/arch2008-01-01_2008-01-31.html. Acesso em: 22 set. 2016.

MARINONI, Luiz Guilherme. Precedentes obrigatórios. $3^{a}$ ed. São Paulo: Revista dos Tribunais, 2013.

MARTINS, André; ROSEMBLATT, Ana. Mediação e transdisciplinaridade. In: ALMEIDA, Tania; PELAJO, Samantha; JONATHAN, Eva (Coord.). Mediação de conflitos para iniciantes, praticantes e docentes. Salvador: JusPodivm, 2016, p. 145-147.

MORAES, Alexandre de. Direito constitucional. 21 a ed. São Paulo: Atlas, 2007.

PEDRON, Flávio Quinaud. As normas fundamentais do CPC/2015 como chaves de compreensão adequada da nova legislação. 2015. Disponível em: https://jus.com.br/artigos/42544/as-normas-fundamentais-do-cpc-2015-como-chaves-decompreensao-adequada-da-nova-legislacao. Acesso em: 18 set. 2016.

REALE, Miguel. Lições preliminares de direito. $27^{\text {a }}$ ed. São Paulo: Saraiva, 2003.

SZTAJN, Rachel. Art. 49. In: PITOMBO, Antônio Sérgio A. de Moraes; SOUZA JÚNIOR, Francisco Satiro de. Comentários à lei de recuperação de empresas e falência. São Paulo: Revista dos Tribunais, 2005. p. 217-268.

TARTUCE, Flávio. O novo CPC e o direito civil: impactos, diálogos e interações. $2^{\mathrm{a}}$ ed. São Paulo: Método, 2016.

THEODORO JÚNIOR, Humberto. Curso de direito processual civil. v. $1.56^{\mathrm{a}}$ ed. Rio de Janeiro: Forense, 2015.

THEODORO JUNIOR, Humberto; NUNES, Dierle; BAHIA, Alexandre Melo Franco; 
PEDRON, Flávio Quinaud. Novo CPC - fundamentos e sistematização. $3^{\mathrm{a}}$ ed. Rio de Janeiro: Forense, 2016.

WAMBIER, Tereza Arruda Alvim. Primeiros comentários ao novo Código de Processo Civil artigo por artigo. São Paulo: Revista dos Tribunais, 2015.

YARSHELL, Flávio Luiz. Convenção das partes em matéria processual: rumo a uma nova era? In: CABRAL, Antonio do Passo; NOGUEIRA, Pedro Henrique (Coord.). Negócios processuais. Salvador: JusPodivm, 2015, p. 161-171. 